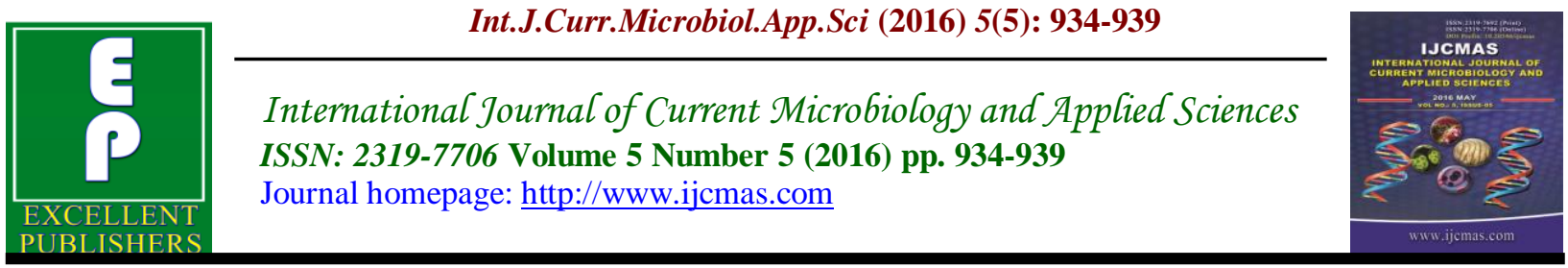

Original Research Article

http://dx.doi.org/10.20546/ijcmas.2016.505.098

\title{
Growth Response of African Giant Land Snail Archachatina marginata Fed on Single Plant Leaves or the Leaves Supplemented with Diet of $25 \%$ Crude Protein
}

\author{
B. N. Ejidike* \\ Department of Ecotourism and Wildlife, Federal University of Technology, \\ P M B 704, Akure, Nigeria \\ *Corresponding author
}

\section{Keywords \\ Archachatina marginata, Plant leaves, Supplemental diet, Growth, Nutrient}

\begin{tabular}{l}
\hline Article Info \\
\hline Accepted: \\
15 April 2016 \\
Available Online: \\
10 May 2016
\end{tabular}

\section{A B S T R A C T}

The effects of plant leaves and supplemental plant leaves on the growth and nutrient utilization of African giant land snail Archachatina marginata were investigated for 168 days. Forty African giant land snail juveniles $(10.0 \pm 4.9 \mathrm{~g})$ were obtained from the University Teaching and Research Farm and stocked five snails per wooden cage of dimensions $1 \mathrm{~m}$ x $0.6 \mathrm{~m} 0.45 \mathrm{~m}$ filled with $15 \mathrm{~cm}$ soil thickness. The wooden cages were raised $10 \mathrm{~cm}$ above the ground with four wooden legs and the African giant land snail was fed at $2 \%$ body weight per day of its specific diet treatment. The diet treatments were fresh green pawpaw leaves, fresh green pawpaw leaves plus $25 \%$ crude protein diet, fresh green sweet potato leaves, and fresh green sweet potato leaves plus $25 \%$ crude protein diet designated diet treatments (I - IV) respectively. Mortality of $30 \%$ was recorded on diet treatment III and no mortality was recorded in the other diet treatments. The mean body weight gain of the African giant land snail in diet treatment II (fresh green pawpaw leaves plus $25 \%$ crude protein diet) was significantly influenced $(p<0.05)$ more than the mean body weight gain of the African giant land snail in the other diet treatments (I, III, IV). No significant difference ( $p>0.05)$ existed among the mean body weight gain of the African giant land snail fed in diet treatments I (fresh green pawpaw leaves) and IV (fresh green sweet potato leaves plus $25 \%$ crude protein diet) that differ significantly $(\mathrm{p}<0.05)$ from the mean body weight gain of the African giant land snail in diet treatment III. Morphological parameters (shell length, shell width) each of the study animal in the diet treatment did not differ significantly ( $>>0.05)$ at the end of the study period. Diet treatments II and IV gave the lowest feed conversion ratio (FCR) of 1.8 each and diet treatment III gave the highest FCR of 3.0. The diet treatments followed the reversed trend in the protein efficiency ratio (PER).

\section{Introduction}

Since civilization animal husbandry has being playing essential role in supplying animal protein as well as other animal products in the dietary and other needs of human. In animal rearing, supplemental dietary protein sources have been in practice 
in most countries with beneficial results. It has been the concern of Nigerian scientists to harness and utilize cheap and locally available protein sources into animal feeds with high yield. Culturing of indigenous animals irrespective of sizes with modern technology would contribute immensely in increasing animal protein intake of the populace. The African giant land snail, Archachatina. marginata, is a delicacy in West Africa and rich in protein and other nutrients such as iron, calcium (Segun, 1975; Imevbore, 1990; Adeyeye, 1996). A. marginata feeds on various plant materials and dead decaying matters in the wild. It thrives well on natural food (plant materials) as well as artificial diet under culturing condition (Ejidike, 2001; Imevbore, 1990). This study investigates the effect of supplementing the plant leaves with artificial diet on the body weight gain for optimum production of the animal under captive farming system.

\section{Materials and Methods}

Juvenile A. marginata ( $\mathrm{n}=40$, mean weight $10 \pm 4.9 \mathrm{~g}$ ) were obtained from the snail pen in the Teaching and Research Farm of the Federal University of Technology, Akure. The snails were acclimated for three days in wooden cage and randomly grouped into five snails per group for the replication of the diet treatments. Each group of the snails were randomly stocked in rectangular wooden cage $(1 \mathrm{~m} \times 0.6 \mathrm{~m} \times 0.45 \mathrm{~m})$ filled with soil up to $15 \mathrm{~cm}$ thickness. The diet treatments were fresh green pawpaw leaves, fresh green pawpaw leaves plus $25 \%$ crude protein diet, fresh sweet potato leaves, fresh sweet potato leaves plus $25 \%$ crude protein diet designated diet (I - IV) respectively. The supplemental diet $25 \%$ crude protein was formulated using locally available ingredients prepared in crumbs. The prepared diet in crumb form was sun-dried at an ambient temperature of $27^{\circ} \mathrm{C}$ for five days. The diet was dried to $12 \%$ moisture content, packed in polyethylene bag and stored in room temperature for subsequent feeding of the experimental animals. The proximate composition of the diet was determined according to AOAC, (1990) Methods. The nitrogen content of the diet was determined by micro-Kjekdahl method following digestion in concentrated sulphuric acid with copper sulphate and potassium sulphate. The experimental snail were fed once daily at $2 \%$ body weight at 1800 hours and the feeding ratio of the plant leaves and diet was 1:1. Individual weighing of the snails was carried out bi-weekly using beam weighing balance. The diets of the snails were adjusted according to the weight of the snails in each cage after sampling.

\section{Statistical Analysis}

Data obtained from the performance of the animals from the study were subjected to analysis of variance (ANOVA) test Steel, and Torrie (1980). Duncan Multiple Range Test (DMRT) was used to separate the means where there was a significant difference (Duncan, 1955).

\section{Results and Discussion}

The ingredient compositions of the supplemental diet are presented in Table 1 which comprises both plant and animal protein sources. Table 2 presents proximate composition of the plant leaves and the supplemental diet. Pawpaw leaves had the highest percent crude protein content while sweet potato leaves and the supplemental diet had similar crude protein content. This high crude protein content of pawpaw leaves might contribute to its highest performance in the body weight gain of the snail. The growth performance of the young African giant land snail fed on the single plant leaves and the single plant leaves supplemented with $25 \%$ crude protein diet is presented in 
Table 3. African giant land snail fed on pawpaw leaves plus $25 \%$ crude protein diet (diet II) attained the highest mean body weight that are significantly $(\mathrm{p}<0.05)$ different from the body weight of the African giant land snail fed on other diet treatments (diets I, III and IV). The mean body weight of African giant land snail fed on pawpaw leaves (diet I) and sweet potato leaves plus $25 \%$ crude protein diet (diet IV) had similar influence $(p>0.05)$ from their specific diet treatment. These results showed that the supplemental diet plays important role in the survival and body development of African giant land snail.

African giant land snail that was fed on sweet potato leaves (diet III) had the lowest mean body weight gain that differs significantly $(\mathrm{p}<0.05)$ from the other diet treatments. The mean morphological parameters (shell length, shell width) of the African giant land snail fed on diet treatment III also had the least mean value that are significantly different $(\mathrm{p}<0.05)$ from the other diet treatments. However, the effect of the other diet treatments (I, II, IV) on the morphological parameters are similar ( $p>0.05)$. The growth patterns of the snail fed on the plant leaves and plant leaves supplemented with $25 \%$ crude protein diet are illustrated on figure 1. The graph demonstrates the rate at which the snail fed on the different diet treatments gain body weight during the study.

Table.1 Ingredient Composition (g/100g) of the Supplemented Diet

\begin{tabular}{lc}
\hline Ingredients & \% \\
\hline Groundnut cake & 10.9 \\
Blood meal & 18.2 \\
Brewer's waste & 10.0 \\
Yellow maize & 41.8 \\
Cocoa husk & 5.0 \\
Bone meal & 1.5 \\
Oyster shell & 1.5 \\
Red palm oil & 6.0 \\
Vitamin premix & 5.0
\end{tabular}

Table.2 Proximate Composition of Plant Leaves and the Supplemental Diet (\% dm)

\begin{tabular}{lccc}
\hline & Diet & Pawpaw leaves & Sweet Potato leaves \\
\hline Moisture & 7.9 & 9.5 & 9.4 \\
Crude protein & 24.8 & 32.7 & 24.7 \\
Crude fibre & 3.7 & 1.7 & 12.1 \\
Crude fat & 3.8 & 0.8 & 10.7 \\
Ash & 9.0 & 11.4 & 11.5 \\
\hline
\end{tabular}


Table.3 Growth and Nutrient Utilization of A. marginata Fed Single Plant Leaves or the Leaves Supplemented with 25\% Crude Protein Diet

\begin{tabular}{lcccc} 
& Diet I & Diet II & Diet III & Diet IV \\
\hline Initial mean body weight $(\mathrm{g})$ & $10.3 \pm 5.2^{\mathrm{a}}$ & $11.5 \pm 6.7^{\mathrm{a}}$ & $9.5 \pm 4.4^{\mathrm{a}}$ & $9.8 \pm 2.8^{\mathrm{a}}$ \\
Final mean body weight $(\mathrm{g})$ & $94.7 \pm 2.5^{\mathrm{a}}$ & $130.8 \pm 3.1^{\mathrm{b}}$ & $35.0 \pm 2.7^{\mathrm{c}}$ & $96.4 \pm 3.8^{\mathrm{a}}$ \\
Mean body weight gain $(\mathrm{g})$ & $84.4^{\mathrm{a}}$ & $119.3^{\mathrm{b}}$ & $26.5^{\mathrm{c}}$ & $86.6^{\mathrm{a}}$ \\
Initial mean shell length $(\mathrm{cm})$ & $3.6 \pm 0.2^{\mathrm{a}}$ & $3.6 \pm 0.2^{\mathrm{a}}$ & $3.6 \pm 0.2^{\mathrm{a}}$ & $3.5 \pm 0.2^{\mathrm{a}}$ \\
Final mean shell length $(\mathrm{cm})$ & $8.1 \pm 0.3^{\mathrm{a}}$ & $9.2 \pm 0.2^{\mathrm{a}}$ & $5.6 \pm 0.3^{\mathrm{b}}$ & $8.1 \pm 0.3^{\mathrm{a}}$ \\
Initial mean shell width $(\mathrm{cm})$ & $2.4 \pm 0.0 .2^{\mathrm{a}}$ & $2.4 \pm 0.2^{\mathrm{a}}$ & $2.4 \pm 0.2^{\mathrm{a}}$ & $2.4 \pm 0.2^{\mathrm{a}}$ \\
Final mean shell width (cm) & $5.1 \pm 0.2^{\mathrm{a}}$ & $5.5 \pm 0.2^{\mathrm{a}}$ & $3.7 \pm 0.2^{\mathrm{b}}$ & $5.0 \pm 0.2^{\mathrm{a}}$ \\
Feed intake $(\mathrm{g})$ & 891.7 & 1042.4 & 383.2 & 793.6 \\
Mortality $(\%)$ & 0.0 & 0.0 & 30.0 & 0.0 \\
DRG $^{1}$ & 0.5 & 0.7 & 0.2 & 0.5 \\
FCR $^{2}$ & 2.1 & 1,8 & 3.0 & 1.8 \\
PER $^{3}$ & 1.4 & 2.0 & 1.3 & 2.2 \\
\hline
\end{tabular}

Figures in the same row having the same superscript are insignificantly different $(\mathbf{p}>0.05)$

$\mathbf{D R G}^{1}=$ Daily rate of growth; $\mathrm{FCR}^{2}=$ Food conversion ratio; $\mathrm{PER}^{3}=$ Protein efficiency ratio

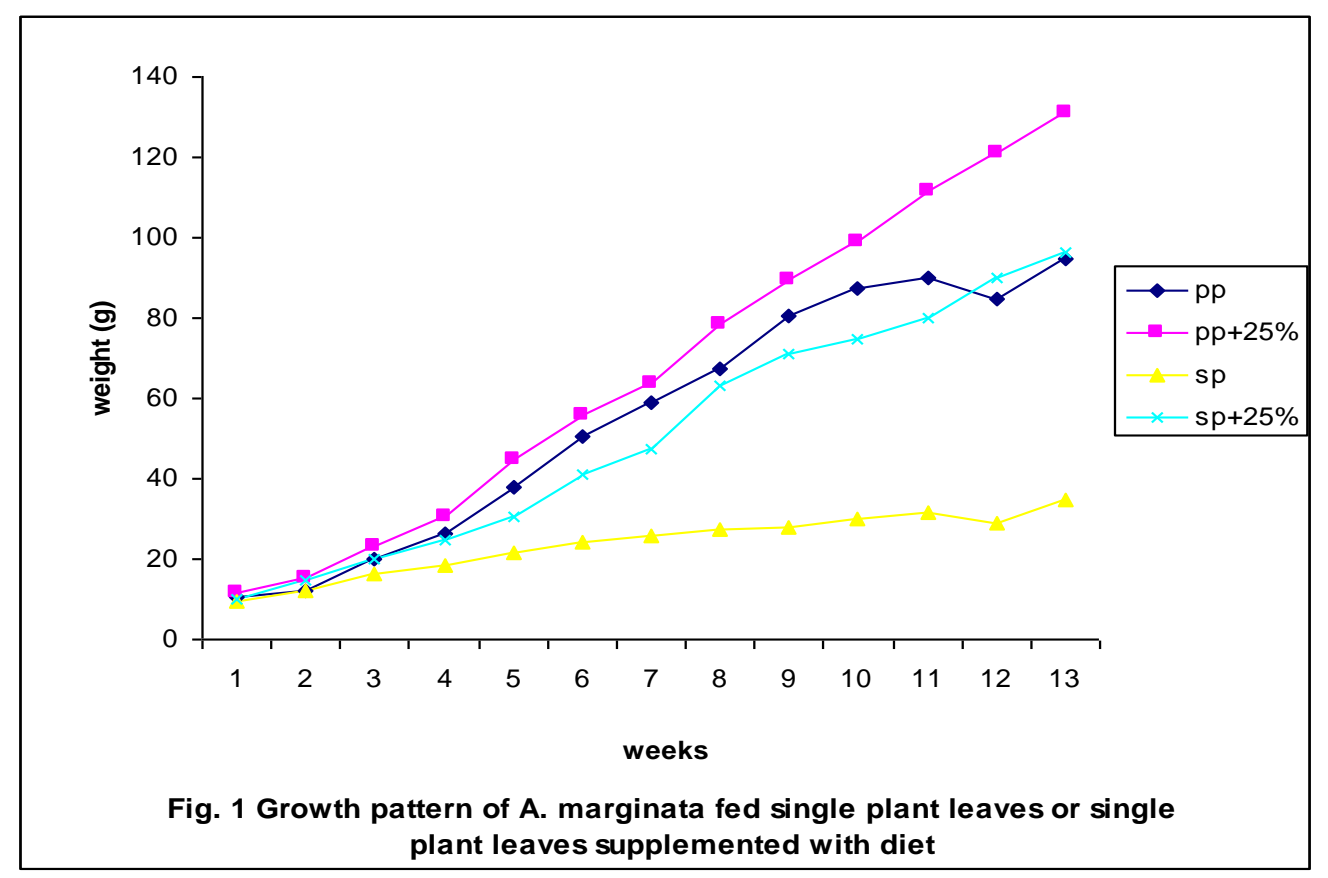

The influence of single plant leaves and supplemental diet on the body weight gain and morphological parameters of African giant land snail was investigated with the view of obtaining the animal's food that will give high survival and optimum body growth. Relatively optimum body weight gain achieved on the snails fed fresh green pawpaw leaves supplemented with $25 \%$ crude protein diet (diet treatment II) that was significantly influenced $(\mathrm{p}<0.05)$ than the body weight gain of the African giant land snail fed on the other diet treatments (I, III, IV) signifies that the supplemental diet of 
$25 \%$ crude protein played a vital role in the nutrition of the animal. This proves supplemental diet necessary in farming of African giant land snail. However, it would be suggested that cost implication of this type of study in future should be considered. It was noted that African giant land snail fed on fresh green pawpaw leaves (diet treatment I) and fresh green sweet potato leaves plus $25 \%$ crude protein diets (diet treatment VI) was similarly influenced (p>.0.05) confirming the important of supplemental diet in the nutrition of the snail hence green pawpaw leaves without supplemental diet had been reported by various authors in their research findings to be optimal suitable for feeding African giant land snail (Egonmwan, 1988; Koudande, and Ehouinsou, 1995; Stievenart, 1996). This also suggested that green sweet potato leaves alone should not be supplied to African giant land snail hence when fed alone on diet treatment III to the animal it poorly influenced the body weight gain and positively influenced the body weight gain of the animal when supplemented with artificial diet (Table 3).

Zero percent mortality was recorded on the other diet treatments within the study period (168 days) indicated that fresh green pawpaw leaves and fresh green sweet potato leaves supplemented with artificial diet are suitable for feeding African giant land snail. This also proves the $25 \%$ crude protein diet relevant to the nutrition of the animal. From the graph the snails fed on fresh green sweet potato leaves had significantly $(\mathrm{p}<0.05)$ low mean body weight gain that started manifesting from the second week of the study. This poor body weight gain and 30\% mortality recorded (Table 3 ) on the snail fed the fresh green sweet potato leaves suggested that the sweet potato leaves might not be suitable as major food for feeding the animal under farming system. However, it could be planted in the farm as food under supplemental condition as well as cover crop for the snails to hide under during the day in order to avoid direct heat from the sun and loss of water from the snail. Shell length and width of the animal fed on diet treatment III (fresh sweet potato leaves) were poorly influenced. The African giant land snail fed on diet treatment III had the highest FCR with relatively low PER and daily growth rate Table 3 , indicating that the nutrients in sweet potato leaves might not be sufficient for African giant land snail to perform well

In conclusion, from the study, it could be noted that not all single plant leaves is suitable as food for African giant land snail. The study also revealed that artificial diet when incorporated in snail food would make for optimum yield of the animal under farming system.

\section{References}

Segun, A. O. (1975) The giant land snail, Archachatina marginata (Swainson). Ethioipe Pulishing House, Benin City, Nigeria.

Imevbore E.A. (1990). Management technique in rearing the African giant land snail Archachatina marginata Swainson. Pp. 288 Ph.D. Thesis submitted to the University of Ibadan, Ibadan Nigeria.

Adeyeye, E. I. (1996) Waste yield, proximate and mineral composition of three different types of land snail found in Nigeria. International Journal of food Science and nutrition. 47 (2) 111-116.

Ejidike, B. N. (2001) Dietary protein requirements of African giant land snail Archachatina marginata Applied Tropical Agriculture, 6: 111-115.

AOAC (1990) Association of Official 
Analytical Chemist (Ed. W. Horwitz). $13^{\text {th }}$ Edition, Washington, D.C

Duncan, D. B (1955). Multiple range test and F.test. Biometrics: 1955; 11: 142.

Steel, R. D. G and J.H. Torrie (1980). Principles and procedures of statistics McGraw-Hill New York.

Egonmwan, R. I. (1988) Reproductive Biology and Growth of land snail Archachatina marginata Ovum and Limicolaria flammea. $\mathrm{PhD}$ Thesis, Oxord University, U.K.

Koudande, O. D. and Ehouinsou, (1995)
Influence of feeding on the production Archachatina sp. FAO n 83, $19952,60-63$.

Stievenart, C. (1996) Shell morphology, growth reproduction and aestivation by African snails: laboratory observations on Archachatina marginata suturalis, Achatina achatina, Achatina fulica. $\mathrm{PhD}$.Thesis, Institute of Tropical Medicine, Antwerp, Belgium. Pp 240.

\section{How to cite this article:}

Ejidike, B. N. 2016. Growth Response of African Giant Land Snail Archachatina marginata Fed on Single Plant Leaves or the Leaves Supplemented with Diet of 25\% Crude Protein. Int.J.Curr.Microbiol.App.Sci. 5(5): 934-939. doi: http://dx.doi.org/10.20546/ijcmas.2016.505.098 